\title{
Awareness and Uptake of Cervical Cancer Screening Among Female Students in School of Basic Medical Sciences, University of Benin, Nigeria
}

\author{
Christie Edoghogho Omorogbe ", Eremwanarue Juliet Ehizemwogie \\ Department of Nursing Science, School of Basic Medical Sciences, University of Benin, Benin City, Nigeria \\ Email address: \\ omorogbechristie@yahoo.com (C. E. Omorogbe) \\ ${ }^{*}$ Corresponding author \\ To cite this article: \\ Christie Edoghogho Omorogbe, Eremwanarue Juliet Ehizemwogie. Awareness and Uptake of Cervical Cancer Screening Among Female \\ Students in School of Basic Medical Sciences, University of Benin, Nigeria. American Journal of Nursing Science. \\ Vol. 8, No. 4, 2019, pp. 163-168. doi: 10.11648/j.ajns.20190804.17
}

Received: February 27, 2019; Accepted: June 5, 2019; Published: June 27, 2019

\begin{abstract}
Cervical cancer screening is an important screening test commonly used to detect abnormal cervical cells, including precancerous cervical lesions, as well as early cervical cancer. Cervical cancer is a deadly disease which can be prevented through screening. Not much has been documented on awareness and uptake of cervical cancer screening among female undergraduate students in the University of Benin. This study investigated the awareness and uptake of cervical cancer screening among female students in School of Basic Medical Sciences, University of Benin. A cross-sectional descriptive survey was conducted among two hundred (200) female undergraduates selected using simple random sampling technique. A pretested structured questionnaire was used to elicit information on respondent knowledge awareness and uptake of cervical cancer screening and was analyzed using the Statistical Package for Social Sciences (SPSS) version 17. Results showed that $86.7 \%$ of the respondents had knowledge of cervical cancer. Eighteen percent have had a screening for cervical cancer. Findings also revealed that the level of uptake of cervical cancer screening is low compared to the level of knowledge about cervical screening. Intensifying the need for nurses to engage in health education and awareness programs that will increase general awareness of the people on the advantages of uptake of cervical cancer screening is essential.
\end{abstract}

Keywords: Cervical Cancer Screening Uptake, Awareness, Cervical Cancer, Female Undergraduates

\section{Introduction}

Cancer of the cervix is a global public health issue as it is the most common gynaecological cancer worldwide. Cervical cancer is a malignant disease of the cervix usually occurring in the 5 th or 6 th decade of life at a mean age of 54 years. The disease has a pre-malignant stage which usually occurs in younger women under the age of 40 [1]. Over $90.0 \%$ of cervical cancer cases are linked to genital infection with human papilloma virus (HPV) ${ }^{2}$. It is estimated to affect approximately 500,000 women annually and $80 \%$ of these cases occur in developing countries with about 500,000 new cases, and the cause of 273,000 deaths each year worldwide, it is the second most common cancer among women [2-4].

The incidence of HPV in young, sexually active women especially students of tertiary institutions is high as the major means of its spread is through sexual contact. Sometimes the virus leads to the development of cervical cancer [5]. According to Owoeye and Ibrahim ${ }^{1}$ several other risk factors are associated with carcinoma of the cervix which includes early age at first sexual intercourse, multiple male sexual partners, male sexual partners who have had multiple partners, early age at first birth, multiparty, smoking, longterm use of oral contraceptive pills, immunosuppressed states. Co-infection with human immunodeficiency virus (HIV), Chlamydia trachomatis, herpes simplex virus type-2, immunosuppressants, and certain dietary deficiencies have also been noted to be associated risk factors for HPV infection [4]. Cervical cancer has been reported as one of the few preventable human cancers because its prevention is based on the early diagnosis of precancerous lesions whose treatment generally makes the development of cancer almost 
impossible [6]. However, this window of opportunity which has enabled the developed countries to reduce the incidence of cancer of the cervix would be wasted if appropriate prevention strategies are not employed. The prevention strategies for cervical cancer comprises of immunization against HPV infection among adolescents prior to the first sexual exposure as a form of primary prevention or screening for evidence of pre-invasive lesions of the cervix among adult females using the Papanicoloau smear (Pap smear) as a form of secondary prevention [7].

Cervical cancer screening is relatively inexpensive and there is worldwide agreement that screening programmes for cervical cancer are a necessity [1]. The Papanicolaou (Pap) smear has been the screening tool commonly used and it has reduced the incidence of cervical cancer in the developed countries by over $70 \%$ where nationally-organized screening programs exist [8]. This positive impact is attributed to the existence of effective national screening programs of cervical cytological testing (the Papanicolaou test) in these countries to identify cell abnormalities that may indicate or precede cervical cancer [1]. According to a study [9] cancer screening using the Pap smear can identify precancerous and potentially precancerous changes in cervical cells and tissue therefore enabling treatment of high-grade changes that can prevent the development of the cancer in many cases.

In developing countries such as Nigeria, several factors which have been noted to have made the screening programs unsuccessful and ineffective in reducing the disease burden are due largely to inadequate personnel and deficiencies in health system infrastructure, presence of limited screening resources, lack of availability or sparsely distributed screening centres [10]. This is further compounded by the fact that both the women and health-care providers in these poor-resource countries often lack information about cervical cancer as a disease entity, its causative agent, and how cost effective it is to prevent it [8].

Uptake of cervical cancer screening in Nigeria is relatively low when compared with other more developed countries such as Canada. In a study conducted on the current knowledge, attitude and practices of female health workers in Sokoto, Nigeria, on cancer of the cervix and cervical screening finding revealed that of the 220 study subjects, only $10 \%$ had ever done the screening test [7]. The most common reason for not assessing Pap smear screening services was the perception that the subjects were not at risk of the disease. Also in the study [11] conducted on cervical cancer screening among female undergraduates and staff in the Niger delta region of Nigeria, findings revealed that out of all the respondents that were used for the study only $12 \%$ of the respondents has had at least one Pap test in the past. The commonest reasons for uptake of screening were; when it is free or subsidized $27.3 \%$ as part of a general screening program $27.3 \%$, Doctor's request $18.2 \%$ and self-conviction $18.2 \%$.

Previous study conducted in Edo State, involving all female that came for cervical cancer screening performed in University of Benin Teaching Hospital (UBTH) findings show out of the 3,284 , women that turned out for screening, $61.5 \%$ had normal smears, $14.6 \%$ had inflammatory smears, $16.2 \%$ had abnormal epithelial lesions while $7.7 \%$ had unsatisfactory smears [12]. World Health Organization [13] identified barriers to cervical cancer screening to include; Lack of awareness of women about cervical cancer screening and insufficient health personnel to carry out this test especially in rural areas. Generally, women's uptake of cervical cancer screening is low especially in developing countries. In most cases, they are ignorant on the importance of the screening. It is therefore important for women, especially the undergraduate students to be empowered on the importance of cervical cancer screening as knowledge is known to influences uptake. There is dearth of information regarding the variables of this study particularly in the University of Benin. This study therefor seeks to investigate the awareness of and uptake of cervical cancer screening among female undergraduate students in School of Basic Medical Sciences, University of Benin.

The objectives are to; (i) assess the knowledge of cervical cancer screening among female undergraduate students in School of Basic Medical Science, University of Benin. (ii) elicit barriers to cervical cancer screening among female undergraduate students in school of Basic medical science, university of Benin and (iii) determine the uptake of cervical cancer screening among female undergraduate students in school of Basic medical science, university of Benin.

\section{Materials and Methods}

A quantitative descriptive (cross sectional) design was adopted as the research design for this study. The study was carried out in the school of Basic medical sciences, university of Benin, Ugbowo campus. The university is situated in Ugbowo community, Egor Local Government of Edo state, Nigeria. Edo State is an inland State in the Central southern part of Nigeria. The institution is situated on 1,748 hectares of land along Benin-Lagos highway. It shares a main boundary with University of Benin Teaching Hospital (UBTH) and Isihor community. It has a population of about 43,000 students made up of full time and part time student. At present it has thirteen (13) Faculties namely, School of Basic Medical Science, School of Dentistry, School of Medicine, Faculty of Physical Science, Life Sciences, Pharmacy, Arts, Agricultural Science, Social Science, Management sciences, Education, Engineering and Law.

The total population of all the female undergraduate students in the school of Basic medical sciences comprised of five hundred and twenty (520) female students from 100 to 500 between the ages of sixteen to thirty (18-30) years from the six departments.

A total of two hundred (200) respondents were recruited for the survey. Respondents were selected using simple random sampling technique. 


\section{Research Instrument}

The Instrument was a validated pre-tested structured questionnaire made up of three sections; Section A; contains items that provided information on demographic profile of the participants, Section B; tapped knowledge about cervical screening and uptake of screening. Twenty questionnaires were pre-tested among twenty undergraduate students who did not participate in the study. The exercise was repeated after two weeks using the same tool on the participants. Overall score were correlated using Pearson coefficient reliability test with a score of 0.754 . Content and face validity was ensured by experts.

The distribution lasted for two (2) days. Data was analyzed using Statistical Package for Social Sciences (SPSS) version 20.0 .

\section{Ethical Consideration}

Permission to carry out the study was sought and obtained from the Ethical review committee of the university following due protocols. The participants were given assurance of confidentiality. They were given the freedom to withdraw at any stage of the study.

\section{Results}

Table 1. Distribution according to age.

\begin{tabular}{lllll}
\hline & Frequency & Percent & $\begin{array}{l}\text { Valid } \\
\text { Percent }\end{array}$ & $\begin{array}{l}\text { Cumulative } \\
\text { Percent }\end{array}$ \\
\hline 18 - 20 Years & 70 & 46.7 & 46.7 & 46.7 \\
21 -25 Years & 66 & 44.0 & 44.0 & 90.7 \\
26 - 30 Years & 14 & 9.3 & 9.3 & 100.0 \\
Total & 150 & 100.0 & 100.0 & \\
\hline
\end{tabular}

Table 1 above shows that the respondents between the ages of 18 - 20 years has the highest frequency $46.7 \%$, while 21 25 years has a frequency of $44 \%$ followed by $26-30$ years with a frequency of $9.3 \%$.

Table 2. Distribution according to marital status of respondents.

\begin{tabular}{lllll}
\hline & Frequency & Percent & Valid Percent & $\begin{array}{l}\text { Cumulative } \\
\text { Percent }\end{array}$ \\
\hline Single & 128 & 85.3 & 85.3 & 85.3 \\
Married & 22 & 14.7 & 14.7 & 100.0 \\
Total & 150 & 100.0 & 100.0 & \\
\hline
\end{tabular}

Table 2 above shows that $85.3 \%$ of the respondents are single while $14.7 \%$ are married.

The academic level of respondents

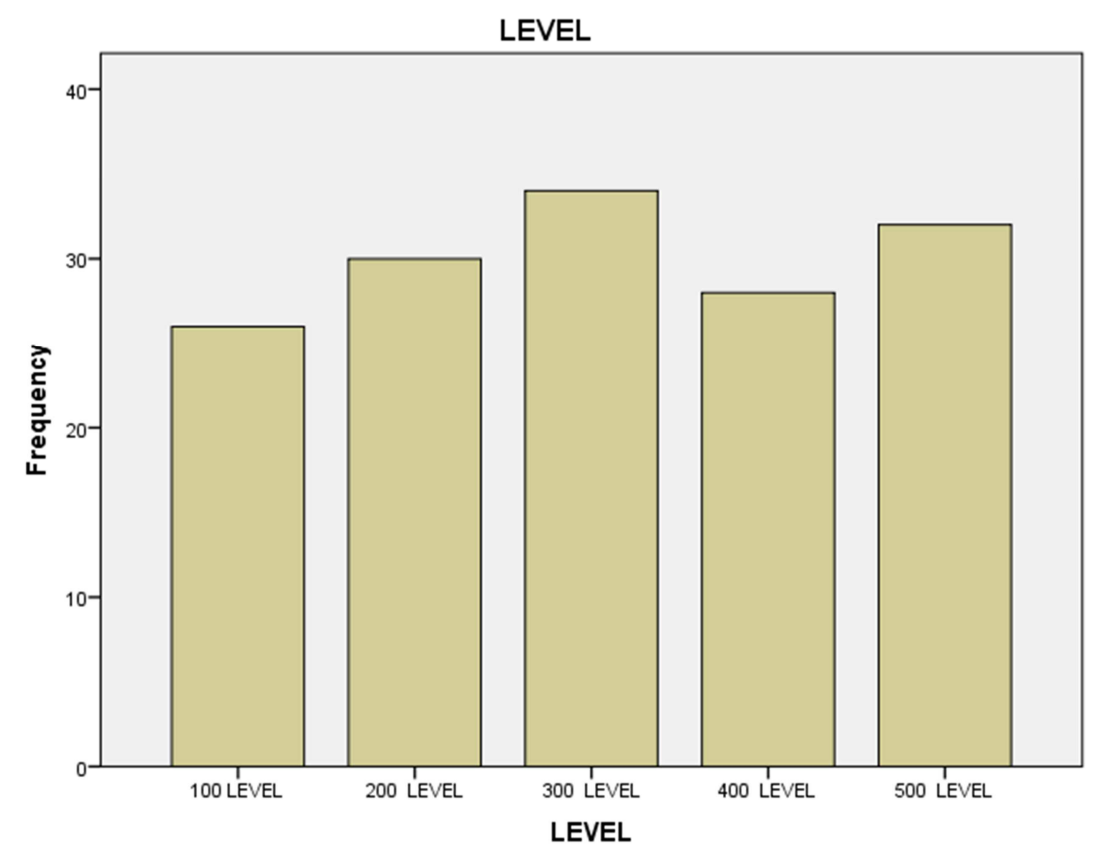

Figure 1. the academic level of respondents.

From the figure above, 17.3 were in 100 level, 20\% were in 200 level, $22.7 \%$ were in 300 level, $18.7 \%$ were in 400 level, while $21.3 \%$ were in 500 level.

Knowledge of cervical cancer

Table 3. Response to the question "have you ever heard of cervical cancer.

\begin{tabular}{lllll}
\hline Response & Frequency & Percent & Valid Percent & $\begin{array}{l}\text { Cumulative } \\
\text { Percent }\end{array}$ \\
\hline YES & 130 & 86.7 & 86.7 & 86.7 \\
NO & 20 & 13.3 & 13.3 & 100.0 \\
Total & 150 & 100.0 & 100.0 & \\
\hline
\end{tabular}

The above table shows that $86.7 \%$ of the respondents have heard of cervical cancer, while $13.3 \%$ of the respondents have not heard of cervical cancer.

Table 4. Response to the question "if Yes, how did you hear about cervical cancer.

\begin{tabular}{lllll}
\hline & Frequency & Percent & $\begin{array}{l}\text { Valid } \\
\text { Percent }\end{array}$ & $\begin{array}{l}\text { Cumulative } \\
\text { Percent }\end{array}$ \\
\hline Health facility & 28 & 18.7 & 21.5 & 21.5 \\
Media & 28 & 18.7 & 21.5 & 43.1 \\
School & 60 & 40.0 & 46.2 & 89.2 \\
\hline
\end{tabular}




\begin{tabular}{lllll}
\hline & Frequency & Percent & $\begin{array}{l}\text { Valid } \\
\text { Percent }\end{array}$ & $\begin{array}{l}\text { Cumulative } \\
\text { Percent }\end{array}$ \\
\hline Friends/relatives & 10 & 6.7 & 7.7 & 96.9 \\
Others & 4 & 2.7 & 3.1 & 100.0 \\
Total & 130 & 86.7 & 100.0 & \\
\hline
\end{tabular}

The table above shows that $18.7 \%$ of respondents heard about cervical cancer at the health facility, $18.7 \%$ of respondents heard about cervical cancer through the media, $40 \%$ of respondents heard about cervical cancer at school, $6 \%$ of respondents heard about cervical cancer through their friends/ relatives, while $2.7 \%$ of respondents heard about cervical cancer through other sources.

Table 5. Response to the question "Have you ever had a test for cervical cancer.

\begin{tabular}{lllll}
\hline & Frequency & Percent & Valid Percent & $\begin{array}{l}\text { Cumulative } \\
\text { Percent }\end{array}$ \\
\hline Yes & 28 & 18.7 & 18.7 & 18.7 \\
No & 122 & 81.3 & 81.3 & 100.0 \\
Total & 150 & 100.0 & 100.0 & \\
\hline
\end{tabular}

The table above shows that $18.7 \%$ have had a test for cervical cancer while $81.3 \%$ have not had a test for cervical cancer.

Table 6. Response to the question "If Yes which of these reasons motivated you to do the test.

\begin{tabular}{|c|c|c|c|c|}
\hline & Frequency & Percent & Valid Percent & Cumulative Percent \\
\hline Doctor's/health practioner's advice & 16 & 10.7 & 57.1 & 57.1 \\
\hline Information from the social media e.g. television, radio, poster & 4 & 2.7 & 14.3 & 71.4 \\
\hline Information from the self-motivated & 6 & 4.0 & 21.4 & 92.9 \\
\hline Total & 28 & 18.7 & 100.0 & \\
\hline
\end{tabular}

The above table shows that $10.7 \%$ of the respondents implied that they were motivated by Doctors/health practitioners advice, $2.7 \%$ opined that they were motivated by information gotten from the social media, $4.0 \%$ got motivated because of underlying disease problem, while $1.3 \%$ pined it was because of advice from family \& friends.

Table 7. Response to the question "Where was it done.

\begin{tabular}{lllll}
\hline & Frequency & Percent & $\begin{array}{l}\text { Valid } \\
\text { Percent }\end{array}$ & $\begin{array}{l}\text { Cumulative } \\
\text { Percent }\end{array}$ \\
\hline At the clinic & 8 & 5.3 & 28.6 & 28.6 \\
At the hospital & 20 & 13.3 & 71.4 & 100.0 \\
Total & 28 & 18.7 & 100.0 & \\
\hline
\end{tabular}

The above table shows that $5.3 \%$ of the respondents did the test at the clinic, while $13.3 \%$ did the test at the hospital.

\section{Discussion}

This research work was carried out with the aim of determining awareness and the uptake of cervical cancer screening among female undergraduate students of the school of basic medical sciences in university of Benin. The findings of the study show that the highest percentage $46.7 \%$ for the age distribution of respondents was between 18-20 years. Majority of the respondent were single $(85.3 \%)$. Also majority of the respondent were Christians (89.3\%). Majority of the respondent were being sponsored by their parents/guardians (84\%). Findings revealed that majority have good knowledge about cervical cancer screening and $(86.7 \%)$ of the respondents have heard of cervical cancer. More than ninety percent of the respondents are aware that cervical cancer affects the cervix while $65.3 \%$ of the respondents know how cervical cancer can be detected. Out of this the percent of the respondents that know how cervical cancer can be detected, only 38\% identified Pap test as a means of detection, $19.3 \%$ identified HPV testing, 5.3\% pelvic examination and $2.7 \%$ colposcopy. Findings of this study is similar to the study ${ }^{9}$ on Knowledge and attitude about cervical screening and HPV vaccine among female medical students of Taif university, in which about $50 \%$ of the medical students that were used for the study had knowledge about cervical screening and same percentage or even more knows about human papilloma vaccination.

The findings of this study is also in agreement with the study conducted [6] on Awareness and knowledge regarding of cervical cancer, pap smear screening and human papilloma virus infection in Gabonese women, in which $91.6 \%$ of the respondents had heard about cervical cancer. The level of these students' knowledge on cervical cancer and its screening is also implicated in screening uptake. Also findings revealed that the level of uptake of cervical cancer screening among female undergraduate students in School of Basic Medical Science, University of Benin is low compared to the level of knowledge about cervical screening. This finding is in agreement with a study conducted ${ }^{4}$ on the current knowledge, attitude and practices of female health workers in Sokoto, Nigeria, on cancer of the cervix and cervical screening, which affirmed that of the 220 study subjects, only $10 \%$ had ever done the screening test. The most common reason for not accessing Pap smear screening services was the perception that the subjects were not at risk of the disease. This finding is also supported by the study conducted [11] on cervical cancer screening among female undergraduates and staff in the Niger delta region of Nigeria. The study revealed that out of all the respondents that were used for the study only $12 \%$ of the respondents has had at least one Pap test in the past. The commonest reasons for uptake of screening were; when it is free or subsidized 27. $0 \%$ as part of a general screening program 27.3\% Doctor's request $18 \%$ and self-conviction were $18 \%$.

On the contrary, a prospective study carried out [12] in Edo State, involving all female that came for cervical cancer screening performed in UBTH revealed that the total number of women that turned out for screening was high. This was high due to the effective measures which were put in place indicating a heightened awareness of cervical cancer. It can 
be seen that generally, that women's uptake of cervical cancer screening is low especially in developing countries. In most cases, they are ignorant on the importance of the screening. Findings also revealed that $69.3 \%$ of the respondents opine that there are difficulties in accessing screening for cervical cancer. However, this finding is at variance with the barriers to cervical cancer screening identified by World Health Organization [13] which includes; Lack of awareness of women about cervical cancer screening and insufficient health personnel to carry out this test especially in rural areas. The study revealed that there is no significant relationship between the knowledge of cervical cancer screening and the uptake of cervical cancer screening among the female undergraduate students. It therefore means that the higher the knowledge of cervical cancer screening, the higher the uptake and vice versa. Hence, it can be concluded that the finding is in agreement with the study conducted [6] on awareness and knowledge regarding of cervical cancer, Pap smear screening and human papilloma virus infection in Gabonese women, in which $91.6 \%$ of the respondents had heard about cervical cancer. The level of these students' knowledge on cervical cancer and its screening is also implicated in screening uptake.

\section{Conclusion}

The study revealed that majority of the students were between 18-20 years of age, and also majority have knowledge about cervical cancer and heard about it in the hospital, despite the knowledge known about the disease, the acceptability of cervical cancer screening was still very low due to fear of embarrassment, cost, stigma, fear of the diagnosis.

\section{Implications for Nursing}

It has been revealed that the level of these students' knowledge on cervical cancer and its screening is also implicated in screening uptake. Since cervical cancer is one of the few preventable human cancers; its prevention is based on the early diagnosis of precancerous lesions whose treatment generally makes the development of cancer almost impossible. There is need for increased awareness and further education of the people on the advantages of uptake of cervical cancer screening.

Nurses should also be trained in preventive strategies of cervical cancer and the available screening methods such as Papaniculaou test, and Visual Inspection with Acetic acid (VIA). These screening methods should be provided in hospitals, primary healthcare centers and school clinics/health centers at an affordable rate so that the female undergraduate students can easily access the service.

\section{Recommendations}

Based on the findings, the following recommendations were made:
1. Enlightenment on cervical cancer screening through seminars, drama, workshops, mass media and lectures on the benefits for the students.

2. Public enlightenment campaign should also be done in market places and even homes to reach the female adolescents and adults especially the illiterates and the singles on the importance of cervical cancer screening and also correct their misconceptions.

3. Nurses should make use of every opportunity to educate students and women on cervical cancer and screening services at every gathering.

\section{References}

[1] Owoeye, I. O. G., \& Ibrahim, I. A. Knowledge and attitude towards cervical cancer screening among female students and staffs in a tertiary institution in the Niger Delta. International Journal of Medical and Biomedical Research, 2013. 2 (1), 4856.

[2] Kashesa, C., Kjaer, S., Mwaiselage, J., Ngoma, T., Terbsol, B., Dartell, M., \& Rasch, V. Determinants of acceptance of cervical cancer screening in Dar es Salaam, Tanzania. BMC Public Health, 2012. 12, 1-8.

[3] Adejuyigbe, F. F., Balogun, B. R., Sekoni, A. O., \& Adegbola, A. A. (2015). Cervical cancer and human papilloma virus knowledge and acceptance of vaccination among medical students in South West Nigeria. African Journal of Reproductive Health, 2015. 19 (1), 140-148.

[4] Oche, M. O., Kaoje, A. U., Gana, Gana. G., \& Ango, J. T. Cancer of the cervix and cervical screening: current knowledge, attitude and practices of female health workers in Sokoto, Nigeria. International Journal of Medical Medicine andMedical Sciences, 2013. 5 (4), 184-190.

[5] Janice, L. H., \& Kerry H. C.. Brunner \& Suddarth's Textbook of Medical Surgical Nursing (13 ${ }^{\text {th }}$ Ed.). Philadelphia, PA: Wolters Kluwer Health / Lippincott Williams \& Wilkins. 2014.

[6] Assoumou, S. Z., Mabika, B. M., Mbuiguino, A. N., Mouallif, M., Khattabi, A., \& Ennagi, M. M. Awareness and knowledge regarding of cervical cancer, Pap smear screening and human papilloma virus infection in Gabonese women. BMC Women's Health, 2015. 15 (37), 1-7.

[7] Ajah, L. O., Iyoke, C. A., Ezeonu, P. O., Ugwu, G. O., Onoh, R. C., \& Ibo, C. C. Association between Knowledge of Cervical Cancer/Screening and Attitude of Teachers to Immunization of adolescent Girls with Human Papilloma Virus Vaccine in Abakaliki, Nigeria. American Journal of Cancer Prevention, 2015.3 (1), 8-12.

[8] Ugwu, E. O., Obi, S. N, Ezechukwu, P. C., Okafor, I. I.,\& Ugwu, A. O. Accepatability of human papilloma virus vaccine and cervical cancer screening among female health-care workers in Enugu, Southeast Nigeria. National Journal of Clinical Practice, 2016, 16 (2), 249-252.

[9] Nisreen, A. A., \& Farzana, R. A. Knowledge and attitude about cervical screening and HPV vaccine among female medical students of Taif University. International Journal of Current Research and Academic Review, 2015.3 (8), 106-112. 
[10] Cunningham, M. S., Skrastins, E., Fitzpatrick, R., Ji dal, P., Oneko, O., Yates, K., Aronson, K. J. Cervical cancer screening and Human Papilloma Virus vaccine acceptability among rural and urban women in Kilimanjaro rejoin, Tanzania BMJ Open, 2015. 5, 1-10.

[11] Isa, I. A., Gana, O. O. I., \& McFubara, K. (2013). Cervical cancer screening among female undergraduates and staff in the Niger delta region of Nigeria. 3, 61-66.
[12] Obaseki, D. E., \&Nwafor, C. C. (2012). Cervical cancer screening in Benin city, South - South Nigeria. IOSR Journal of Dental and Medical Sciences, 5 (1), 16-19.

[13] World Health Organization. Liberia: Cervical Cancer, World Health Rankings. Retrieved January 22 ${ }^{\text {nd }}, 2017$ from: http://www.worldlifeexpectancy.comliberia-cervical-cancer 2014. 